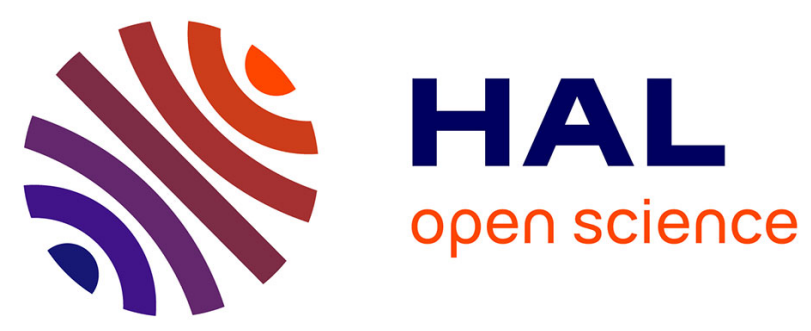

\title{
Chemical characterization of water extractable organic matter from plants: A better understanding of soil dissolved organic matter sources and path in permafrost thawing regions
}

\author{
Alienor Allain, Marie Anne Alexis, Yannick Agnan, Guillaume Humbert, \\ Edith Parlanti, Mahaut Sourzac, Amélie Guittet, Christelle Anquetil, \\ Emmanuel Aubry, Véronique Vaury, et al.
}

\section{- To cite this version:}

Alienor Allain, Marie Anne Alexis, Yannick Agnan, Guillaume Humbert, Edith Parlanti, et al.. Chemical characterization of water extractable organic matter from plants: A better understanding of soil dissolved organic matter sources and path in permafrost thawing regions . EGU General Assembly 2021, Apr 2021, online, France. 10.5194/egusphere-egu21-12002 . hal-03184151

\section{HAL Id: hal-03184151 \\ https://hal.sorbonne-universite.fr/hal-03184151}

Submitted on 29 Mar 2021

HAL is a multi-disciplinary open access archive for the deposit and dissemination of scientific research documents, whether they are published or not. The documents may come from teaching and research institutions in France or abroad, or from public or private research centers.
L'archive ouverte pluridisciplinaire HAL, est destinée au dépôt et à la diffusion de documents scientifiques de niveau recherche, publiés ou non, émanant des établissements d'enseignement et de recherche français ou étrangers, des laboratoires publics ou privés. 
EGU21-12002, updated on 29 Mar 2021

https://doi.org/10.5194/egusphere-egu21-12002

EGU General Assembly 2021

(c) Author(s) 2021. This work is distributed under

the Creative Commons Attribution 4.0 License.

\title{
Chemical characterization of water extractable organic matter from plants: A better understanding of soil dissolved organic matter sources and path in permafrost thawing regions
}

\author{
Alienor Allain ${ }^{1}$, Marie Anne Alexis ${ }^{1}$, Yannick Agnan ${ }^{1,2}$, Guillaume Humbert ${ }^{3}$, Edith Parlanti ${ }^{4}$, \\ Mahaut Sourzac ${ }^{4}$, Amélie Guittet ${ }^{1}$, Christelle Anquetil ${ }^{1}$, Emmanuel Aubry ${ }^{1}$, Véronique Vaury ${ }^{3}$, and \\ Maryse Rouelle ${ }^{1}$ \\ ${ }^{1}$ Sorbonne Université, CNRS, EPHE, UMR METIS, F-75252 \\ ${ }^{2}$ Earth and Life Institute, Université catholique de Louvain, 1348 Louvain-la-Neuve, Belgium \\ ${ }^{3}$ Sorbonne Université, CNRS, UMR iEES Paris, F-75252, Paris, France \\ ${ }^{4}$ Université de Bordeaux, CNRS, EPHE, UMR EPOC, F-33405, Talence, France
}

In present permafrost thawing context, dissolved organic matter (DOM) is a key component that controls organic and inorganic material transfer from soil to hydrographic systems. In terrestrial environments, vegetation is the main source of DOM, before degradation by microorganisms. DOM stoichiometry, aromaticity, composition or quantity control its fate, and referential data characterizing the initial DOM originating from plant biomass leaching are scarce.

To better understand its dynamic, this study focuses on the characterization of water extractable organic matter ("WEOM": a proxy of DOM) of main plant species belonging to different plant functional types typical of the subarctic region (lichen, willow, birch, and Eriophorum).

Dissolved organic carbon (C) and dissolved nitrogen (N) contents of WEOM samples were measured, as well as organic C and total $\mathrm{N}$ contents of ground plant leaf samples ("bulk" samples). $\mathrm{C} / \mathrm{N}$ ratio of bulk samples and WEOM fractions were compared to evaluate the potential extractability of $\mathrm{C}$ and $\mathrm{N}$. The composition of both WEOM and bulk samples were characterized through solid state ${ }^{13} \mathrm{C}$ Nuclear Magnetic Resonance (NMR) and compared. Absorbance and 3D fluorescence measurements were also performed on WEOM samples to characterize their optical properties.

WEOM is significantly more extractable in vascular plants compared to non-vascular ones. Moreover, $\mathrm{N}$ is more extractable than $\mathrm{C}$ in all lichen species and Eriophorum, whereas $\mathrm{C}$ is as extractable as N in Salix and Betula pubescens samples. Betula nana is the only species with C more extractable than $\mathrm{N}$.

The solid state ${ }^{13} \mathrm{C}$ NMR spectra of bulk sample are very similar to the spectra of corresponding WEOM, except for Eriophorum. For this species, carbonyl C contributes to $5 \%$ of bulk sample spectrum, compared to $14 \%$ of the WEOM spectrum. 
Based on absorbance measurements, optical index were calculated: E2/E3 is significantly higher for non-vascular plants, whereas E2/E4, E3/E4 and slope ratio $\left(S_{R}\right)$ do not show significant difference between plant functional types. In 3D fluorescence spectra, the contribution of "Proteinlike" peak is lower for vascular plants compared to lichens, and is maximum for Eriophorum.

Our results highlighted the influence of plant species on the quantity and quality of produced DOM: WEOM production process is different between vegetation species due to the quality, especially hydrophobicity and extractability of bulk OM components. The high contribution of C-N bonds in WEOM of Eriophorum might be especially important for potential complexation between DOM and trace elements like cadmium (Nigam et al., 2000). Likewise, aromatic C observed only in vascular plant WEOM samples are known to bond have a good affinity with many elements like iron, vanadium and chromium (Gangloff et al., 2014). Under climate change, vegetation cover of the Arctic region is evolving with the moving of the treeline northward and a local increase of the proportion of shrubs (Berner et al., 2013). Accordingly, significant change of DOM composition are expected with potential influence on organic and inorganic material dynamics.

Berner et al., (2013). Glob. Chang. Biol. 19:3449-3462

Gangloff et al., (2014). Geochim. Cosmochim. Ac. 130:21-41

Nigam et al., (2000). Chem. Speciation Bioavailability 12:125-132 